\title{
THE AGE AT MENARCHE IN ASSAM AND BURMA
}

\author{
BY \\ C. V. FOLL \\ From the Burma Oil Co. (1954) Ltd., Rangoon \\ (RECEIVED FOR PUBLICATION AUGUST 17, 1960)
}

Most of the reports from India on the age at menarche have been based on recollected ages of commencement of the periods and the accuracy of these is doubtful. Examples of such ages vary from 13.42 years (Israel, 1959) based on replies from 2,227 women from different parts of India to 14.88 years (Shah, 1958) based on questionnaire forms completed by 2,391 Hindu girl entrants to Gujerati University, Ahmedabad, in West Central India. Two other series are quoted by Shah from the same area of India-989 girls of Maharaja Sayajirao University during 1950, 1951 and 1952, had an average recollected age at menarche of 13.8 years, and during 1954, 2,370 girls in high schools in Poona had an average recollected age at menarche of 14.06 years.

The technique adopted in this study was to ask the girls their age and whether or not they had started menstruating. From the data obtained (Tables 1 and 2) the average age of onset of menstruation was calculated by the statistical technique of probit analysis. In Assam this average age was found to be $13 \cdot 21 \pm 0 \cdot 11$. In a study in Burma by Foll (1958) a menarcheal age of $14 \cdot 40$ was reported; unfortunately the calculation was in error, and the corrected value is $13.25 \pm 0.08$. In both these series the probit technique gave an excellent fit to the data. The standard deviation in Assam was 1.62 years and in Burma 1.12 years.

The 1,150 girls in the Digboi, Assam, series were mostly Assamese, Bengalis and Nepalis with a few Central and Southern Indians, and the majority came from Hindu families, although there were some Buddhists, Sikhs, Christians and Muslims. In the Chauk, Burma series, the 702 girls were predominantly Burmese Buddhists, with a few Chinese, Indians or Anglo-Indians. If the method of probit analysis is to be used with success it is essential that the girls being interviewed should have an accurate knowledge of their ages, and ages in the tropics are notoriously unreliable. It is only in communities where accurate birth dates are required for making personal horoscopes (e.g. in Burma where Birth Notices in the Press often include the exact time, to the nearest second, of the birth) or where there is a settled community having adequate birth records, e.g. in some missions or amongst an industrial company's employees that any accuracy may be expected.

Studies by probit analysis have been reported by Wilson and Sutherland (1953), and include a series by Ellis (1950) in Southern Nigeria (Thomson 1952), and their own work in Nigeria, Ceylon and England. Their results are summarized in Table 3 and compared with the Assamese and Burmese findings.

TABLE 1

NUMBER OF GIRLS AND AGE AT MENARCHE IN DIGBOI, UPPER ASSAM

\begin{tabular}{|c|c|c|c|}
\hline \multirow{2}{*}{$\begin{array}{c}\text { Age } \\
\text { (years) }\end{array}$} & \multicolumn{2}{|c|}{$\begin{array}{c}\text { Numbers Having First } \\
\text { Menstrual Loss }\end{array}$} & \multirow[t]{2}{*}{ Total } \\
\hline & Yes & No & \\
\hline $\begin{array}{r}8 \\
9 \\
10 \\
11 \\
12 \\
13 \\
14 \\
15 \\
16 \\
17\end{array}$ & $\begin{array}{r}0 \\
3 \\
3 \\
11 \\
39 \\
45 \\
45 \\
37 \\
22 \\
6\end{array}$ & $\begin{array}{r}181 \\
207 \\
193 \\
167 \\
101 \\
65 \\
18 \\
6 \\
1 \\
0\end{array}$ & $\begin{array}{r}181 \\
210 \\
196 \\
178 \\
140 \\
110 \\
63 \\
43 \\
23 \\
6\end{array}$ \\
\hline Total & & & 1.150 \\
\hline
\end{tabular}

TABLE 2

NUMBER OF GIRLS AND AGE AT MENARCHE IN CHAUK, UPPER BURMA

\begin{tabular}{|c|c|c|c|}
\hline \multirow{2}{*}{$\begin{array}{c}\text { Age } \\
\text { (years) }\end{array}$} & \multicolumn{2}{|c|}{$\begin{array}{c}\text { Numbers Having First } \\
\text { Menstrual Loss }\end{array}$} & \multirow[t]{2}{*}{ Total } \\
\hline & Yes & No & \\
\hline $\begin{array}{l}10 \\
11 \\
12 \\
13 \\
14 \\
15 \\
16 \\
17 \\
18\end{array}$ & $\begin{array}{r}0 \\
1 \\
8 \\
49 \\
71 \\
100 \\
74 \\
47 \\
20\end{array}$ & $\begin{array}{r}72 \\
91 \\
85 \\
58 \\
20 \\
3 \\
1 \\
2 \\
0\end{array}$ & $\begin{array}{r}72 \\
92 \\
93 \\
107 \\
91 \\
103 \\
75 \\
49 \\
20\end{array}$ \\
\hline Total & & & 704 \\
\hline
\end{tabular}


TABLE 3

AGE AT MENARCHE IN NIGERIA, CENTRAL INDIA, CEYLON, BURMA AND ASSAM, COMPARED WITH SOUTHERN ENGLAND*

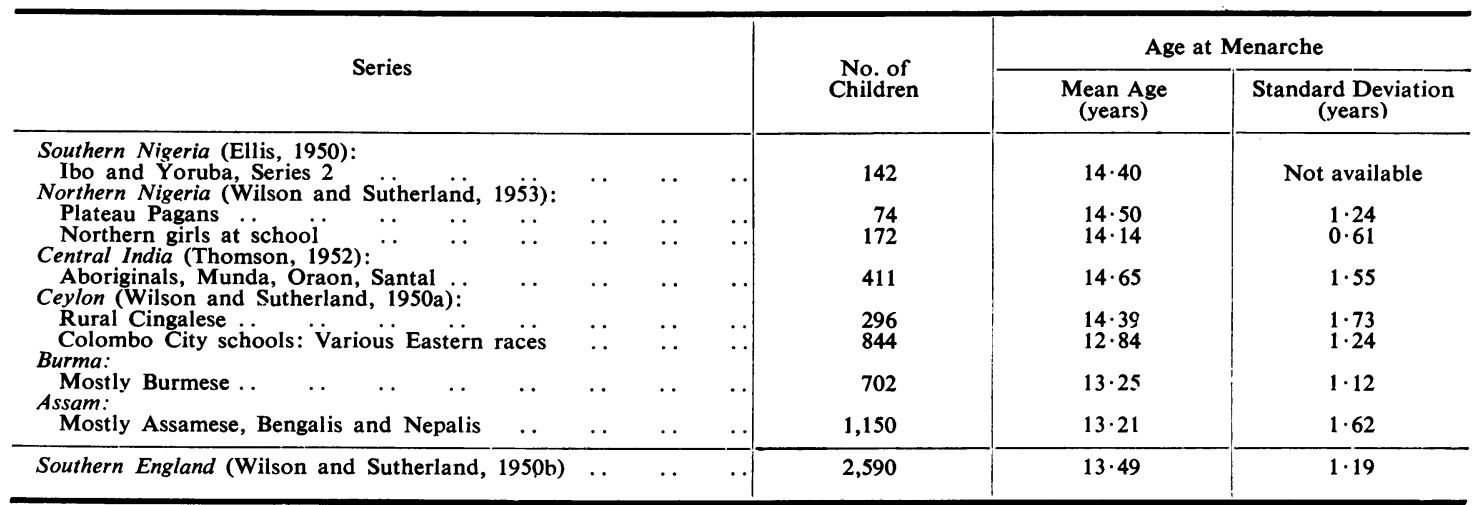

* All data obtained from probits.

\section{Factors that may Influence the Age at Menarche}

Most girls start menstruating between the ages of 9 and 18, and outside these wide limits, puberty may be considered precocious or delayed, the cause being either over-activity or lack of activity of one or more members of the endocrine system. For the purpose of this report these two groups of cases may be ignored.

The factors to be considered here as affecting the age at menarche are race, climate, nutrition and socio-economic position.

Race. In the past, it was stated frequently that Jewish girls started menstruating early and Eskimo girls late. The truth of the latter has been questioned by Levine's (1953) finding that the age at menarche of Alaskan Eskimo girls was 14.4 years. Ito (1942) showed that in Los Angeles there were significant differences in the age at menarche of American, European, Japanese, Negro and Chinese girls at the same college. However, even this study may not be free from nutritional or socio-economic conditions. Ellis (1950) has written: 'Heredity, ... . whilst it may affect the age of puberty of the individual, is probably not of major importance when communities of different ethnic stock living under similar social and environmental conditions are compared.' However, in India it is difficult to find different ethnic stocks living in the same place under similar social conditions, and this study throws little light on this aspect of the problem.

Climate. The data for Table 3 were obtained from places in the world which had considerable variation in their climates. Lagos, lying about
450 miles north of the Equator in Southern Nigeria, has an average annual rainfall of 72 in. and a humid atmosphere with temperatures rising to $90^{\circ} \mathrm{F}$. On the other hand, the Northern Nigerian Savannah is hot and dry, and the plateau temperate. In the Assam-Burma series, Chauk, a town of some 25,000 inhabitants, is situated in the 'dry zone' of Burma almost 1,500 miles north of the Equator, and has an average rainfall of 24 in. with temperatures rising to $112^{\circ} \mathrm{F}$. In contrast, Digboi, a town of about 60,000 inhabitants in Upper Assam, and approximately 450 miles due north of Chauk, has an average rainfall of 120 in. with temperatures in the wet summer months rising to over $100^{\circ} \mathrm{F}$. Thus the two groups of girls (of different races) lived under vastly different climatic conditions, although their socio-economic conditions were similar and the basic item of diet, rice, was the same. The ages at menarche were $13 \cdot 21$ (Assam) and 13.25 (Burma). Similarly, in Nigeria, where again there were considerable climatic differences, the ages at menarche were $14 \cdot 40$ (Southern) and 14.14 (Northern).

It is suggested that the effect of climate has been unduly stressed in the past. The pendulum of opinion has swung back from the view that children mature earlier in the tropics, and possibly overswung to the view of Mills (1937) who states 'sexual maturity in tropical countries comes fully two years later than in most stimulating temperate regions'. Wilson and Sutherland (1953) write: 'It is, however, clear that in tropical countries the onset of menstruation is not determined solely by the climate'. In spite of animal experiments in which it was shown that a hot moist atmosphere may retard sexual maturity (Ogle, 1934), it is considered doubt- 
ful whether, in fact, climate plays any part in affecting the age at the onset of the menses.

Nutrition and Socio-economic Position. It is impossible to discuss nutrition adequately without reference to the socio-economic position of the girls because the latter largely determines the former. The girls in this series, both in Assam and Burma, were daughters of oil company employees and must be considered as economically better placed than the average in either country. Ellis (1950) writes that 'Since school children in Nigeria represent a privileged section of the community, it may be assumed that the nutrition of those included in the survey would be above the average of children in the southern provinces generally, where probably less than $20 \%$ of girls of school-age are in fact attending school'. The evidence for stating that higher socio-economic groups mature earlier has been detailed by Tanner (1955). In her All-India survey, Israel (1959) found that girls from the higher income groups were younger at menarche than those from less well-to-do homes.

Nutrition is probably the most important of the many causes for this socio-economic difference. Ellis (1950) has described the Southern Nigerian diet as being largely vegetable (yams, cassava, cornflour, plantains, etc.) with little meat and no milk, but with some fish. The Burmese diet is based on rice, with vegetables and occasionally meat curry. Fish is plentiful in Chauk since it lies on the east bank of the Irrawaddy and is usually used as a soft tasteful paste (Ngapi) in preparing the Burmese curry and soup (hingyo) or as 'Balachaung' a mixture of Ngapi, dried prawns and chillies. Both these preparations provide a valuable additional source of protein. Cow and buffalo milk is seldom given to children. The great majority of children in Burma are well nourished and food taboos are rare (Foll, 1959), as contrasted with the protein cultural blocks of Bengal (Jelliffe, 1957). In Assam, there are modifications in the diet due to the different ethnic groups. On the average, weaning takes place later than in Burma and nutritional deficiencies in children are commoner. The basic items of the diet are dhal (legume) and rice, the latter being of a much poorer quality than in Burma and often considerably adulterated with dirt, stones, etc. Milk, also adulterated, is drunk by children, but green vegetables and vegetable broths are seldom eaten.

In neither place is malaria a problem, never occurring in Chauk and now very rare in Digboi.
The incidence of intestinal infestation (particularly ascaris) was appreciably higher in Digboi than in Chauk.

It would be of considerable interest to carry out regular surveys of the age at menarche in the so-called socially undeveloped countries and note whether any change in age occurs with social development.

\section{Summary}

The age at menarche in Assam calculated by probit analysis is $13.21 \pm 0.11$ with a standard deviation of 1.62 and in Burma is $13.25 \pm 0.08$ with a standard deviation of $1 \cdot 12$ (the latter figure being a correction to a previous study).

The two groups of girls were from a privileged section of the community.

Of the factors that may influence the age at menarche it is submitted that climate plays no part, race but little, and that socio-economic circumstances and nutrition are most important.

I am most grateful to Dr. Tanner, of the Department of Growth and Development, Institute of Child Health, London, for his help and encouragement, and also for the care with which he and Mr. Howard Simpson of the Department of Statistics, Rothamsted Experimental Station, Harpenden, have checked my attempts at statistical calculation.

\section{REFERENCES}

Ellis, R. W. B. (1950). Age of puberty in the tropics. Brit. med. J., 1,85 .

Foll, C. V. (1958). Physical development of schoolgirls in Upper Burma. Arch. Dis. Childh., 33, 452

(1959). An account of some of the beliefs and superstitions about pregnancy, parturition, and infant health in Burma. J. trop. Pediat., 5, 51 .

Israel, $S$. (1959). The onset of menstruation in Indian women. J. Obstet. Gynaec. Brit. Emp., 66, 311.

Ito, P. K. (1942). Comparative biometrical study of physique of Japanese women born and reared under different environments. Hum. Biol., 14, 279. (Quoted by Tanner, 1955.)

Jelliffe, D. B. (1957). Social culture and nutrition. Cultural blocks and protein malnutrition in early childhood in rural West Bengal. Pediatrics, 20, 128.

Levine, V. E. (1953). Studies in physiological anthropology.III The age of onset of menstruation of the Alaskan Eskimo. Amer.J. Phys. Anthrop., n.s. 11, 252. (Quoted by Tanner. 1955.)

Mills. C. A. (1937). Geographic and time variations in body growth and age at menarche. Hum. Biol., 9, 43.

Ogle, C. (1934). Adaptation of sexual activity to environmental stimulation. Amer. J. Physiol., 107, 628.

Shah, K. A. (1958). The age of menarche in Gujerati college giris J. Indian med. Ass., 30, 347.

Tanner, J. M. (1955). Growth at Adolescence. Blackwell, Oxford Thomson, C. (1952). Personal communication. Quoted by Wilson and Sutherland (1953).

Wilson, D. C. and Sutherland, I. (1950a). Age at the menarche. Brit. med. J., 1, 1267.

(1950b). Further observations on the age of the menarche Ibid., 2,862 .

2, 607 .

\section{Erratum}

In a study in Burma by Foll (1958), a menarcheal age of 14.40 years was reported; the calculation was in error and the corrected value is $13 \cdot 25 \pm 0.08$. 